\title{
Customization-Massing-New Angle of View to Implement C2B Development in China
}

\author{
Xin Song, Lei Tang \\ City Institute, Dalian University of Technology, Dalian, China \\ Email: 17573693@qq.com
}

How to cite this paper: Song, $\mathrm{X}$. and Tang, L. (2017) Customization-Massing-New Angle of View to Implement C2B Development in China. American Journal of Industrial and Business Management, 7, 735-740. https://doi.org/10.4236/ajibm.2017.76052

Received: May 5, 2017

Accepted: June 9, 2017

Published: June 12, 2017

Copyright $\odot 2017$ by authors and Scientific Research Publishing Inc. This work is licensed under the Creative Commons Attribution International License (CC BY 4.0).

http://creativecommons.org/licenses/by/4.0/

\begin{abstract}
In Consumer to Business (C2B) mode driven by consumer demand, enterprises must not only meet the requirements of individual customers, but also take into account the trade-off between cost and profit. Customization-massing becomes the core model successfully implementing the C2B. This article analyses and expounds the principle and the main way of realizing C2B by customization-massing from two aspects "personalized marketing" and "flexible production", and proposes "Intelligent manufacturing" and " $3 \mathrm{D}$ technology" will be the future direction of $\mathrm{C} 2 \mathrm{~B}$ development in China.
\end{abstract}

\section{Keywords}

Customization-Massing, Consumer to Business, Mass Customization, Flexible Production, Personalized Marketing

\section{Introduction}

In China, C2B was created by Alibaba, and currently had been mentioned twice by Prime Minister Li Keqiang at important meetings which attracted wide attentions. The $\mathrm{PM}$ states that $\mathrm{C} 2 \mathrm{~B}$ refers to the fact customers propose requirements, and manufacturers design goods and equipment that the customers require. This is a true revolution! An enterprise is not a closed enterprise anymore; it is connected to the market by Internet and has effective communication with customers at any time. This is the main trend!

C2B is e-commerce mode, means Consumer to Business. It is business model which is customer centered and pushes product design and production process by market requirement. In fact, back to 2008, Ma Yun put forward that C2B mode will come along in the postindustrial era ten years later which is the future of industrial upgrading, and internet goods will let all customers have the customized product. C2B mode could let ordinary consumers really enjoy the high level service of "noble class". The temptation for the vast majority of ordinary 
consumer groups is self-evident.

At the same time, along with the China's main consumer groups familiarizing in Internet applications, the traditional B2C's information asymmetry between buyers and sellers will be gradually broken, which gives customers more personalized requirements and experiential consumer demand. In addition, at today's big data environment, the rapid development of mobile e-commerce also provided more referential data information and convenient online shopping ways (transaction mode and payment mode). All of these will accelerate the process of Chinese consumers' demands for personalized, and expectation for $\mathrm{C} 2 \mathrm{~B}$ mode. It is not difficult to see the demand driven by $\mathrm{C} 2 \mathrm{~B}$ model is quietly rising in China, or will become one of the most representative business models of the big data era enjoyed by the vast of Chinese consumers.

\section{Unique Characteristics of "Customization-Massing"}

Customization-massing means enterprises drive by personalized orders, searching the same or similar modules and component parts, producing and assembling the parts in large scales.In this way; they could not only meet the needs of individual consumers, but also get the benefits of economy of scale.

In China, the concept of "customization-massing" was suggested by Wang, J.Z. et al. who divided mass customization into two different processes: mass-customizing and customization-massing. They researched the balance model of mass customization and the application method and key technology of customization-massing [1]. Before that, the scholars at home and abroad had explored and researched mass customization in various aspects. Jiao et al. put forward to determine whether the products had customizability could from three aspects: design customizability, process customizability and customer perception of value [2] [3]. Tseng et al. indicated in the mass customization system, in such aspects as instruments, production plan and product design, there was a large number of similarities that could be integrated and optimized scientifically, which would contribute to reduce the complexity of manufacturing system [4]. Wu and Qiu considered that group technology was a new technology used in mass customization production model in the period of big data [5]. Yang and Qi thought that there were many similarities of different products and processes in the mass customization system, and the key were how to identify and effective use of these similarities [6].

In conclusion, the current researches on mass customization are standing in the perspective of supply chain, which pay a close attention to a large number of similarities in the aspects of customer demand, product design and production planning, and meanwhile, focus on how to obtain the advantages of economies of scales from these similarities, so as to reflect or own the advantages of "push-pull system". It is on the basis of the standardization of products and the scale effect, the different customer requirements are segment in order to make the finished product diversification, through modular design and mass production. Then, meet the individual needs of different customers better, making the 
maximum profit.

Nevertheless, the researches above have ignored one problem, that is, for mass customization, taking into account the modular design and production, the degree of personalization in the product is subject to a lot of constraints, consumer demand for personalization cannot be completely released.Moreover, in the future mass customization also cannot universally meet the personalized requirements of customization customers' who use C2B model to consume. Hence, this article will regard "customization-massing" as an optimization of "pull system" to carry on research. That is, the customized production process could start at ordering, researching and designing stage. At the same time, it has the advantage of scale economy of the same or similar modular production between individual products. It became an important model that both meet the individual consumers' requirements and allow enterprises to gain profits. Furthermore, the author will innovative research why and how to utilize "customization-massing" to achieve C2B. This article will respectively analyses and expounds the principle and the main way of realizing $\mathrm{C} 2 \mathrm{~B}$ by customization-massing from two aspects: "personalized marketing" and "flexible production".

\section{3. "Customization-Massing” Will Help C2B Successful Landing}

The core of $\mathrm{C} 2 \mathrm{~B}$ is driven by the requirements of customers. It is up to customers to decide production's "what", "how many" and "when". C2B is not a single ring, but relates to all nodes of the production, sale and consumption areas throughout supply chain. The main components of the C2B model include "customers define value", "personalized marketing", "flexible production", and "pull supply chain". Specifically, if the enterprise wants to truly take the consumer as the center of the $\mathrm{C} 2 \mathrm{~B}$, they must have personalized marketing means to capture the fragmented and diversified demands, also utilize the "pull system", and even take large-scale social collaboration to achieve the rapid production of varieties and small batches commodity. Furthermore, "customization-massing" can take full advantages in the aspect of "personalized marketing" and "flexible production", which will provide tremendous value and help $\mathrm{C} 2 \mathrm{~B}$ successful landing.

\section{The Main Ways to Achieve C2B Mode by "Customization-Massing"}

In China, "C2B" and "Customization-massing" are new terms; new things for the majority of consumers, some e-commerce companies lead the industry and become pathfinders. At present, the customization-massing's approaches to achieve C2B mainly in the following two aspects.

\subsection{Using a Variety of Personalized Marketing Tools to Achieve the Scale Advantage of Sales Volume and Order Processing}

Try to make consumers' fragmentation demand reach a certain size through some marketing means, not only can expand sales volume to increase profits, but also can obtain scale advantages of the order processing, reduce the cost of 
sales. At the same time, they can provide consumers' opportunities to do online interactive module selection and product design by the information technology, even bring consumers a new service experience, and also, increase the proportion of flexible production. The main forms of personalized marketing are as follows.

\subsubsection{Presale Customization}

Presale customization means enterprises collected demands of consumers and carried out deposit advanced sale and controlled the customized pre-sale scale to have "hunger marketing" effect. Typical examples like "iPhone" and "MI phone".

\subsubsection{Interactive Product Research and "Fans Economy"}

Interactive product research and development utilise the effective interactive between enterprise and consumers on the internet platform. Let the consumers aim to the specific situation of the future product function, carry out more comprehensive and practical voting and discussion. Then, Implement the optimization design product according to requirement information. This method brings customer brand new participate experience; get direct feedback information, and then the product users will gradually develop into products and brands "fans". Form "fans economy" with high loyalty and stable demands by fans. Such like well-known "XIAO MI" phone in China, they invited "MI fans" fully participated in the development of mobile phones, system trial. And improved the design by the feedbacks from fans to form a standard mode "fans-advanced sale-custom". It is worth mentioning that "XIAO MI" sells over 1 million phones in several days under the supporting of MI fans.

\subsubsection{Modular Customization}

Modular customization means enterprises provide consumers with several functional modules and appearance modules; so that consumers are free to create personalized products, then do the customized production. In fact, this kind of mode possesses low level of personalization; the consumers only can do the arrangement and combination of functional modules. Such as the air-conditioner customization activity called "Freestyle" by $T C L$ and JingDong, it let consumers to customize the appearance, function and remote control. They could select 6 out of 22 functions such like energy saving, sterilization, remote control etc., and 1 from 4 panels to create customer's own air conditioner.

\subsubsection{Cooperation with Large Online Retailers' Business Platform}

All types of enterprises can use the flow advantages of large online retailers' business platform, rapid convergence of consumer demands, to establish a good interactive relationship with consumers at low cost, and provides a full range of services to achieve C2B model. For example, in 2014 ten Chinese small appliances brands with ALI's powerful business platform and large data processing capabilities, only 1 day, had sold 180 thousand units of small household electrical appliances in "Tmall" and "Juhuasuan" platform which customize the design 
and production by the consumers.

\subsection{Seek the Sameness/Similarity of Products Required by the Consumers to Reflect the Scale Effect of Modular Production}

In order to support the front-end of $\mathrm{C} 2 \mathrm{~B}$ model, the back-end must have mass production to reduce the high cost of customization. Design and produce the sameness or the similarity of products from personalized requirements, so as to obtain the cost advantage of mass production of modular components. This has become one of the important ways to help increase the customization-massing profitability.

\subsubsection{Modularity}

Modular method refers to the division and design of a series of modules; meet the different requirements of consumers through producing different products by the modules' selection and composition. It emphasizes on the generalization and standardization, serves for the large-scale production, which can reduce the cost.

\subsubsection{Product Family Technology}

Product family technology refers to upon the analysis of consumer demand, based on the basic product; add different personalized modules to meet the diverse requirements of different consumers and produce a group of related products. When develop and design products, it is necessary to consider whether the product can be extended to a family of products and meet the current demand for orders at the same time. Try to use standard or similar product structure to expand the user groups; preference should also be given to use standard or generic components to expand the size of the same parts, and then lower the cost.

\subsubsection{Group Technology}

Group technology is categorizing the enterprises' products or components by the structure shape and the process, take the group as the object, carry out the mass production of various parts of the group, and reduce the cost. To achieve this, the product design must be flexible and personalized.

\section{5. "Customization-Massing” Is the Future Direction to Achieve C2B Landing}

\subsection{Through "Intelligent Manufacturing" to Achieve Flexible Production}

Flexible production is the key to make profit of small batch customization. In future, by the help of every kinds of advanced intelligent information technology, such like bar code recognition technology, intelligent software, dynamic programmable robots, digital sensors, smart tags, interconnected sensor drive system etc. the flexible production will be achieved. Products can be turned upon the customers' habits and usage, or use predictive analysis to ensure that components/modules will be replaced at the end of service life. For example, the 
device recognizes the processing instructions by reading the two-dimensional code on the material and the workpiece. And those could do automatic handling, cutting, polishing, grinding and other different processes. Furthermore, quick switch from single customization, small batch, mass production through agile programming to fulfill the market demand for different levels of SKU production.

\section{2. “3D Technology" Will Be New Profit-Making Point of Customization-Massing at Big Data Era}

In the big data era, enterprises can easily do the online analysis to the collected data through the "3D" scanning technology, and generate independent "3D digital model", which can easily calculate the matching level of personalized design for a particular thing or person, and adjust timely, which will improve customer satisfaction for customized products greatly. Although, in China nowadays, the "3D" scanning technology still costs a fortune, and it is hard to promote large-scale application. However, the accuracy and speed of the calculation are much higher than the manual calculation. And it can greatly shorten the order lead time, therefore create impressive profit space. In USA, companies like Styku had already reduced the " $3 \mathrm{D}$ " scanning hardware costing to 3000 dollars and promoted a large number of "3D terminals". We look forward to the "3D scan" technology popularize in China in the near future.

\section{References}

[1] Wang, J.Z., Wang, S.Y. and Yang, Y., et al. (2014) Customization-Massing: A New Perspective on Mass Customization. Modern Manufacturing Engineering, 24, 136-140.

[2] Jiao, J.X., Tseng, M.M., Vincent, G.D., et al. (1998) Product Family Modeling for Mass Customization. Computer \& Industrial Engineering, 35, 495-498.

[3] Jiao, J.X. and Tseng, M.M. (2004) Customizability Analysis in Design for Mass Customization. Computer-Aided Design, 36, 745-757.

[4] Tseng, M.M., Lei, M. and Su, C.J. (1997) Collaborative Control System for Mass Customization Manufacturing. CIRP Annals-Manufacturing Technology, 46, 373 -376 .

[5] Wu, X.Y. And Qiu, X.L. (2001) From Group Technology to Mass Customization. China Mechanical Engineering, 12, 319-321.

[6] Yang, Q.H. and Qi, G.N. (2007) The Principle of Mass Customization. Chinese Journal of Mechanical Engineering, 43, 89-97. 
Submit or recommend next manuscript to SCIRP and we will provide best service for you:

Accepting pre-submission inquiries through Email, Facebook, LinkedIn, Twitter, etc. A wide selection of journals (inclusive of 9 subjects, more than 200 journals)

Providing 24-hour high-quality service

User-friendly online submission system

Fair and swift peer-review system

Efficient typesetting and proofreading procedure

Display of the result of downloads and visits, as well as the number of cited articles Maximum dissemination of your research work

Submit your manuscript at: http://papersubmission.scirp.org/

Or contact ajibm@scirp.org 